RESEARCH ARTICLE

\title{
Against Anti-Democratic Shortcuts: A Few Replies to Critics
}

\author{
Cristina Lafont
}

In this essay I address several questions and challenges brought about by the contributors to the special issue on my book Democracy without Shortcuts. In particular, I address some implications of my critique of deep pluralism; distinguish between three senses of 'blind deference': political, reflective, and informational; draw a critical parallelism between the populist conception of representation as 'embodiment' and the conception of 'citizen-representatives' often ascribed to participants in deliberative minipublics; defend the democratic attractiveness of participatory uses over empowered uses of deliberative minipublics; clarify why accepting public reason constraints does not imply limiting deliberation to questions about constitutional rights; and argue that overcoming a state-centric conception of democracy does not require replacing the 'all subjected' principle with the 'all affected' principle.

Keywords: deference; deliberation; values; public; citizenry; deliberative democracy; democratic legitimacy; minipublics; representation

The combination of thought-provoking, critical, sharp, charitable, and fruitful comments that my critics have provided are the sort of comments that every author craves. These comments also show how much truth there is to the saying that interpreters understand a work much better than its author. I cannot discuss all the interesting issues, questions, and challenges raised by these comments. Properly responding to all of them would require multiple papers, even books. My hope is that these brief replies are the first step in an ongoing dialogue. Given that several commentators discuss some of the same central topics from different angles, I shall focus on each of these 'big' issues instead of trying to (within space constraints!) fully respond to each of the contributions. I shall address the topics in the order that they arise within the overall structure of the book.

\section{Is Political Agreement Possible? Nailing Down the Critique of Deep Pluralism}

In his comments, Jürgen Habermas correctly points out that my critique of deep pluralist conceptions of democracy is incomplete. In order to really 'nail down' such a critique I would need to show that normative statements are capable of being justified at all. As he very plausibly contends, 'if moral statements, which constitute the controversial core of political questions, were not capable of being true at all, every deliberative exchange of reasons for and against normative statements

Northwestern University, US

clafont@northwestern.edu in political debate would become pointless.' (Habermas, this issue: 12) I agree. A full defense of the claim that political disagreements can be reasonably overcome requires a metaethical analysis that successfully uncovers the overarching standards that can be used to justify normative statements in general. I do not offer such an analysis in the book. Had I done so, I would have defended a non-reductive interpretation of discourse ethics that explains the internal relation between moral rightness and discursive agreement without equating the one to the other. As indicated in his comments, Habermas rejects this interpretation because he fears that it amounts to a form of moral realism that assimilates the meaning of assertoric validity claims to normative ones. In my view, these fears are unfounded. Over the last several decades, we have had an ongoing debate where I have tried to show that only the non-reductive interpretation of discourse ethics can avoid the anti-fallibilistic consequences of the constructivist interpretation that Habermas favors, according to which discursive agreement is not simply indicative but constitutive of moral rightness. ${ }^{1}$ Be that as it may, I did not include this (or any other) metaethical debate in the book for a particular reason. Doing so could have misled readers into thinking that my criticism of deep pluralism hinges upon a successful defense of a particular metaethical position. However, I believe that the deep pluralist approach collapses under the weight of its own internal difficulties.

Like any other conception, deep pluralists are trying to give a plausible account of democratic practices whose features exist independently of any of the competing accounts. In particular, deep pluralists essentially 
rely on the existence of heated and ongoing political disagreements among citizens. They should therefore be able to give a plausible account of such a salient practice. My criticism tries to show that they simply cannot do this. Since background agreement is a condition of the possibility of meaningful disagreement, disagreement simply cannot go all the way down, as deep pluralists claim. Indeed, ongoing disagreements provide the best evidence for the existence of political agreement (which enables disagreements to be focused, have directionality, produce domino effects, and so forth). Deep pluralism is reflectively unstable precisely because it runs up against key preconditions of the practices it aims to explain. Citizens could not endorse it while simultaneously keeping such practices intact. Therefore, my criticism does not hold deep pluralism up to a deliberative ideal that it rejects. Instead, I scrutinize deep pluralism through the lens of a practice that they themselves attempt but (if my criticisms are plausible) fail to explain.

Habermas also questions the possibility of meaningfully separating the task of justifying claims in general from the task of justifying claims to others. This is an important issue that I should clarify in order to avoid any possible misunderstandings. If I understand his objection correctly, it is motivated by an important hermeneutic insight that I did not discuss in the book. Namely, we cannot adopt a third-personal attitude towards reasons. Reasons can only be identified as such from the internal perspective of someone who is evaluating their quality as persuasive or valid reasons. Thus, once I succeed at providing reasons that will persuade others it will be already too late for me to ask what I myself should believe. As Gadamer puts it, what is plausible 'passes into one's own thinking on the subject' (Gadamer 1994: 375). If this is the case then figuring out what is correct or best and justifying it to others cannot be two separate processes; there is not one process whereby I convince myself of what is correct/best and then another, entirely separate process, whereby I try to persuade others with reasons that they can accept (even if I do not find those reasons convincing). I want to be clear that I am not trying to question the internal connection between understanding and evaluation. Indeed, in my opinion that connection holds not only within normative disputes but also amidst disagreements over facts. Moreover, although I do not explicitly discuss it in the book, I actually rely on this connection to defend the claim that deliberation can empower. Let me briefly indicate how the pieces of this argumentative undercurrent hang together.

In the book the point of differentiating between general justification and justification to specific others within a given political context is to highlight what goes wrong with epistocratic (and lottocratic) shortcut proposals. Defenders of these proposals take political justification to be a purely epistemic task. They are concerned with maximizing the chances of figuring out the 'right' or 'best' policies. If one adopts this purely epistemic perspective then it seems plausible to suppose that any improvement in the epistemic credentials of those who participate in deliberation and decision-making would help identify and enact better policies 'faster' and that this would also benefit ignorant non-participants. After all, in purely epistemic discourses it is the quality of the reasons that really matters rather than the identity of the participants that bring them to the fore. As such, why not delegate deliberating to those with the best epistemic credentials, as we do in scientific or legal discourses? Why do we have to justify the policies that we favor to our fellow citizens regardless of their epistemic qualifications? Or, to put the question in Habermasian terms, why do political debates have to include the views of all those affected? And why should decisional majorities take the views of disempowered minorities seriously if they do not find them plausible on their merits?

In contrast to purely epistemic discourses (scientific, moral, ethical, etc.), when we engage in political discourses we are not simply making up our minds about what the right views are. We are also talking about the imposition of coercion on others who have equal rights to be co-legislators. In scientific discourses it can be very helpful to disregard irrelevant or long-disproven views in order to figure out the right views 'faster.' However, in political discourses the situation is different. We not only have to figure out what the right policies are but we must also ensure that imposing these policies on others is legitimate. This means that those subjected to the policies in question have to be assured of their rightness so that they too could obey them of their own accord. This is why public deliberation must focus on the actual views, interests, and policy objectives of our fellow citizens, however wrongheaded they may seem to those who disagree with them. In politics, citizens do not get to choose their deliberative partners based on their epistemic credentials. For they owe justifications not simply to (whoever they consider) their epistemic peers but also to all those over whom they exercise coercion. The fact that some consideration matters to citizens-even if they are in the minority-means that this consideration must be assessed within public deliberation and properly addressed by counterarguments rather than simply ignored by the decisional majority.

My example of a conversation between a mother and her son tries to illustrate this idea. The point is not to focus on a case where one side got the facts right and the other got them wrong. Rather, the point is to show that, even if the empowered side of a policy debate is convinced that the weaker side is entirely wrong on the merits, they still owe the weaker side a justification that takes their views and concerns seriously. Only in this way could the weaker side be able to come to endorse the policy of their own accord rather than being coerced into sheer obedience. The example illustrates this idea from the perspective of the empowered side. But this idea could be illustrated equally well from the perspective of the weaker side. If we change the example from 'no texting while driving' to, say, 'no eating a vegan diet' we can easily imagine the empowered mother having the same impressions about the implausibility of her son's vegan views and arguments while, at the same time, the unforced force of the better argument eventually comes to prevail against the mother's views. Deliberation can be genuinely empowering to those on the weaker side of power inequalities precisely because of the internal connection between understanding and 
evaluation. But deliberation can be empowering only if those on the stronger side fulfill their democratic obligation of justifying their favored policies to those who will be subject to them by engaging with their views, values and arguments and, by so doing, opening their own views up to the risk of being undermined by the unforced force of the better argument.

\section{Blind deference and Anti-Democratic Shortcuts}

In retrospect I should have more clearly explained my use of some key terms in the book such as 'blind deference' and 'shortcuts.' With respect to the latter I often point out that I am not against all shortcuts. It would have been better to add an adjective to distinguish the shortcuts I reject from those I endorse. After publishing the book, I started using the expression 'anti-democratic shortcuts' in order to highlight that I am not arguing against just any old shortcuts but rather only against those shortcuts that bypass political deliberation among the citizenry and thereby undermine the democratic ideal of self-government. Of course, this distinction opens up a lot of questions about the types of shortcuts that are democratically defensible, why and how they could be beneficial to a deliberative system, and so on. While I find these types of questions very interesting and important, I do not address them in the book. The book focuses on shortcuts that are anti-democratic to the extent that they expect or require citizens to blindly defer to the political decisions of others. So, the key term here is 'blind deference.' I offer a brief definition of the term in the Introduction. However, reading some of the contributions here made me realize that a more extensive discussion of the use of the term would have been helpful.

I use the term 'blind deference' to refer to a case in which a person deferring to some agent has no reason to expect the agent's decisions to coincide with the decisions that she herself would have made if she had thought about it with access to the relevant information. For all she knows, the agent's decisions could go either way. Thus, the 'blindness' in question has to do with the potential lack of alignment between the agent's decisions and those that the person deferring to the agent would endorse upon reflection, based on her political interests, values, and policy objectives. The term 'blind' marks the limiting case at one side of the spectrum when the agent has no reason at all to expect alignment. As soon as the person has some reason to expect alignment then the deference involved is not-blind in that sense. I will call having no reason to expect alignment politically blind deference. An example of politically blind deference would be a voter who selects among the representatives included on the ballot by tossing a coin. This voter would have no particular reason to expect that the representatives she happens to choose will make political decisions that align with her interests, values or policy objectives. For all she knows, the decisions of those representatives can go either way. I argue in the book that expecting or requiring citizens to defer to the political decisions of the majority (of the citizenry or of a random sample) is equally politically blind.
Certainly, the term 'blind' can be used to mark other aspects of deference. It could be used in a more general sense to refer to cases in which one has no reason at all to defer to a particular agent. Under this understanding of the term, as soon as one exercises some judgment to choose a particular agent, deference is not 'blind.' Yet, notice that this use of the term has nothing to do with the first one. I may exercise judgment in choosing a specific agent without my judgment having anything to do with the likelihood that the agent's decisions coincide with those I myself would make upon reflection. I may choose an agent because I think that the agent is more likely to make correct (or better) decisions than I am. Since alignment is not at issue, the potential 'blindness' (or lack thereof) in such a case has to do with other features (such as the level of reflection, information and so on). Under this alternative understanding of the term, the stronger my reasons to defer to a specific agent the less blind my deference is, even if, for all I know, the agent's decisions could go directly against what I myself would have decided upon reflection. I will call having no reason at all, alignment to the side, reflectively blind deference.

Yet another aspect of deference for which the term 'blind' could also be meaningfully used is to indicate the level of information that the person deferring to an agent has about the issues to be decided upon. If the person knows nothing about the issues in question the person is deferring 'blindly' in that sense. However, this would not necessarily be a case of blind deference in my sense of the term. Even if I know nothing at all about some highly technical decisions, I still wouldn't be blindly deferring if I had some reason to believe that the agent I am deferring to will make the same decisions I would make if I were properly informed. I will call knowing nothing about the issue informationally blind deference.

In the book I am exclusively concerned with the first sense-politically blind deference. But let me briefly summarize how the other two senses of 'blind deference' bear on the question of democratic control. Reflectively blind deference is sufficient for a lack of control. But its absence is not sufficient to establish control because it is compatible with politically blind deference. By contrast, informationally blind deference is compatible with control in the absence of politically blind deference. This is why informational shortcuts can be perfectly compatible with participatory deliberative democracy. Keeping these distinctions in mind helps to address several contributors' comments on the topic of blind deference.

\section{Politically vs Reflectively Blind Deference}

As I make clear in the book, I have no objections to 'deference' in the sense of delegation. I am not arguing for direct democracy. I only object to 'blind' deference. Now, in my usage, 'blind' is qualitatively different from 'non-blind' and, for the purposes of my argument, there are no degrees of 'blindness.' In other words, whereas nonblind deference may come in degrees, blind deference is the limiting case at one end of the spectrum that I reject. In their comments, Jane Mansbridge and Robert Goodin use the term in the opposite way. For them 'non-blind' deference (or 'full endorsement') is the limiting case in 
which citizens maintain direct control over some political decisions whereas all cases of indirect control or lack of control count as 'more or less blind.'

The reason I do not use the distinction in their way is because I do not aim to establish a preference for direct over indirect forms of democratic control, nor do I wish to defend the view that nothing short of 'full endorsement' of laws and policies is democratically acceptable. Rather, my aim is to criticize a particular type of lack of control as unacceptable from a democratic point of view because it undermines equal opportunities of securing endorsement. I also aim to show that the alternative approach I defend does not include this type of lack of control. However, for this argument to succeed the alternative I defend does not have to be able to secure direct control or full endorsement. Arguing against the option at one end of the spectrum is one thing. Endorsing the option at the opposite end of the spectrum is quite another. Doing the former is compatible with endorsing any of the available options between both ends of the spectrum. My critical claim is that a set of political institutions that requires or expects citizens to blindly defer to the decisions of the majority (either of the citizenry or of randomly selected groups) may realize political equality but that it lacks democratic control and is therefore incompatible with the democratic ideal of selfgovernment under any minimally plausible understanding of that ideal. Since my argument focuses on the limiting case of 'lack of control,' I use 'blind' deference to refer to that case and leave 'non-blind' deference unspecified so that it covers all other possible cases, i.e. indirect as well as direct or immediate forms of control.

There are many ways that citizens can lack control over the political decisions to which they are subject but, for the purposes of my argument, I am interested in the extent to which citizens have equal (effective and ongoing) opportunities for control over the substantive content of those decisions. In my usage, the distinction between blind and non-blind deference is similar to Mark Warren's distinction between warranted and unwarranted trust. $^{2}$ Deference is warranted or not-blind if one has some (defeasible) reason to assume that those to whom one is deferring share one's interests, values and policy objectives whereas deference is blind or unwarranted if one has no reason to make that assumption at all. In the first case, one has a reason to assume that the political decisions endorsed by the agent to whom one is deferring are those that one would make if one thought through the issue with access to the relevant information. By contrast, in the second case, one has no reason to make this particular assumption; for all one knows, the agent's decisions could go either way.

Thus, for the purposes of my argument what matters is not how direct or indirect the control one has is, but rather how it bears on the substantive content of the decisions that one is subject to. Mansbridge seems to assume that so long as citizens authorize and agent or institution to make political decisions and maintain the right to revoke that decision no blind deference is involved. I disagree. One can freely decide to blindly defer to the decisions of others but the fact that it is a free decision does not make it any less blind in the relevant sense. ${ }^{3}$ If I decide to blindly defer to the political decisions of others, whatever those decisions might be, I am consenting to no longer participate as an equal in shaping those decisions. The fact that I freely chose to defer to some agent has no bearing on whether the agent's decisions will be aligned with my interests, values and policy objectives and thus on whether I will be able to identify with them and endorse them as my own. To claim that free consent is sufficient for democratic self-government would be like claiming that citizens who authorize a dictator to make all political decisions for them live in a democracy so long as they can revoke their decision at a future time.

This brings me to two interesting scenarios of deferring to majority rule that Goodin discusses in his comments. In one of the hypothetical scenarios a citizen is:

convinced of the validity of Taylor (1969) and Rae's (1969) proof that, under certain conditions, majority rule is the decision rule that uniquely maximizes the frequency of your getting your way (i.e., having your beliefs and values being enacted into law). (Goodin this issue: 27).

Would deferring to the majority under these conditions count as a case of blind deference in my sense? I agree with Goodin that it would not, but I am not sure that we agree for the same reasons. In my view, this hypothetical case, as described, is indistinguishable from the standard case in which citizens elect representatives whose decisions they think are likely to coincide with what they themselves would have decided in the relevant context. In both cases, far from deferring blindly, citizens choose the agent they are deferring to precisely for the (defeasible) reason that they think it is the choice most likely to lead to political decisions that are aligned with their interests, values and policy objectives and thus the decisions that they can come to own and identify with. ${ }^{4}$ By contrast, in the second hypothetical scenario that Goodin discusses a citizen has read Estlund's (2008) book and has 'come to believe that majority voting is the procedure that is most likely to yield epistemically correct conclusions.' (Ibid: 27) Since deferring to majority decisions under these conditions would be the result of exercising judgment, it would not be a case of reflectively blind deference. But would it be a case of politically blind deference? Of course, it would: correct decisions might very well not be aligned with my interests, values, and policy objectives at all. If that were so, then I would not be able to identify with them and endorse them as my own. Consenting to blindly defer to others is not an oxymoron. It may be even beneficial. But it isn't participating in democratic self-government.

Goodin suggests that the second case does not involve (politically) blind deference because in both cases one is 'engaging in a project of self-government on two levels: you (together with others) decided the community's decision rule, and you (together with others) provide the inputs that produce community decisions under that rule' (Ibid: 27). I disagree. Whereas in the first case it is understood that the democratic goal of 'having your 
beliefs and values being enacted into law' is the legitimate goal that justifies the decision rule in question, in the second case the decision rule is justified by the epistocratic goal of getting the correct decisions enacted, regardless of whether or not they are aligned with your own beliefs and values. In this case deference is (politically) blind precisely because you are consenting to obey decisions regardless of whether you can evaluate them as aligned with your own beliefs and values. It can hardly get any blinder than that! But here Goodin makes an additional suggestion. What if some citizens believe that 'being correct' is the preeminent virtue of social decisions? Wouldn't citizens with such beliefs and values be engaged in a project of self-government? Wouldn't they be able to identify with majoritarian decisions and endorse them as their own just because they are likely to be correct?

I do not think that this is possible. Making beliefs, values, or norms your own means that you integrate them within the inferential network of beliefs, values, and norms that you endorse. You cannot take yourself out of that process. Acquiring new beliefs typically requires adjustments and revisions to other beliefs that are inferentially connected to them in order to keep overall consistency in our web of beliefs. ${ }^{5}$ In order to do this one needs to identify which specific beliefs need adjustment or revision and why. Yet, this evaluative process is incompatible with blindly deferring to others. Any belief, value, or norm might be justified for a variety of mutually incompatible reasons and, depending on what those reasons are, other beliefs, values or norms will need to be revised. Knowing that a belief or decision is (likely to be) correct is not enough to know what follows from endorsing it and what other beliefs or decisions are incompatible with that endorsement. Instead, knowledge of the latter depends on the other things you happen to believe and endorse.

Think of political decisions about contested ethical practices (abortion, euthanasia, or gene editing) or those about contested economic policies (privatization of pensions, free trade, or universal basic income). Any particular decision about any of these issues could be justified for a variety of mutually incompatible reasons. Knowing that the majority favors a view (e.g. legalizing gene editing for human embryos), and being willing to adhere to their verdict because it is likely to be correct is not sufficient to incorporate this belief into your web of beliefs and make it your own. In order to do that you need to assess which of your other beliefs and values are incompatible with it (and must therefore be rejected) and also which beliefs and values follow from it (and must therefore be endorsed on pain of inconsistency). Is gene editing of human embryos permissible because gene editing is harmless in general and thus a fortiori harmless for embryos too? Or is it permissible because the potential life-saving benefits far outweigh the risks? If so, who will be at risk and what are the risks? Are any risks to individuals justified for the benefit of the greater number? Is gene editing of human embryos permissible because utilitarianism is correct? If this is so, then one should, on pain of inconsistency, endorse utilitarianism when assessing other policies as well. Is the permissibility of human embryo gene editing compatible with believing that human life begins at conception? Or must this belief also be rejected on pain of inconsistency? Is belief in God incompatible with this endorsement? These questions can be multiplied indefinitely. The point is simply that endorsing such decisions and making them your own means evaluating them as correct on the basis of your own beliefs and values so that you can update the latter accordingly and make needed adjustments. No one else can do this for you. You may blindly obey decisions but you cannot blindly make them your own. Blindly accepting the verdicts of majority decisions, whatever they might be, is not a way of engaging in self-governance-it is an abdication of it.

\section{Politically vs Informationally Blind Deference}

This raises an additional issue. Is deference blind if I lack information about the issues that are going to be decided by the agent I am deferring to? In other words, does the use of informational shortcuts necessarily involve some degree of blindness? Not according to my use of the term 'blind.' The use of informational shortcuts bears on how knowledgeable citizens need to be about political questions in order to make proper decisions about them. Using informational shortcuts can dramatically decrease the level of knowledge required among the citizenry and this is why such shortcuts are so incredibly useful. However, the (political) 'blindness' of deference bears specifically on how likely it is that the decisions made by the agent one is deferring to will be aligned with one's own interests, values and policy objectives. These are two separate issues and are not necessarily correlated. In my opinion, deferring to majorities (of either the citizenry as a whole or of random samples) counts as using a blind shortcut because a citizen who accepts majority verdicts ex ante (i.e. simply because they are those of the majority), has no particular reason to expect them to go one way or another and thus, a fortiori, no reason to expect that these decisions will be aligned with her interests, values, and policy objectives. By contrast, if a citizen uses a shortcut because she thinks that it is likely to yield a political decision that is aligned with her interests, values, and policy objectives then there is no (political) blindness involved, regardless of how little the citizen herself knows about the political issue in question. Naturally, citizens may be wrong about the reliability of the shortcut. But being wrong is not the same as being blind.

Looking at André Bächtiger's and Saskia Goldberg's 'enhanced shortcut approach' from this perspective, it is not clear to me why they qualify it as involving 'semiblind' deference. I suspect that they are using the term 'blind' in the informational sense noted above, but not in the political sense that I am concerned with in the book. Following my usage, the fact that you exercise your own judgment and freely consent to defer to a particular agent does not make your deference any less blind if, for all you know, the agent's decision could go either way. By contrast, if you defer to an agent because you think that the agent's decision is likely to be aligned with what you would choose if you were in the relevant 
situation then such deference does not count as blind even if you have no pre-existing opinion on the particular issue and no intention to exercise your own judgment in forming such an opinion. In my sense of the term, 'semiblind' deference would mean that one has some reason to expect the agent's decision to be aligned with one's own beliefs and values, but the reason is weak, so the likelihood of alignment is not very high (even if it is the highest among the available alternatives). Citizens often face this situation when electing representatives they are not very excited about. But I don't think that this is what Bächtiger and Goldberg mean by 'semi-blind deference.' For, as far as I can see, none of the uses of minipublics that they discuss and endorse would lead non-participants to make political decisions that are unlikely to be aligned with their interests, values, and policy objectives or that could go either away. Let's take a look at their examples.

In the first case that they discuss, the minipublic's majority recommendation confirms one's pre-existing opinion on the political issue in question. In such a case, the authors claim "there is nothing wrong if we "blindly" defer to the minipublic recommendation in case of preference alignment with the majority of the minipublic.' (Bächtiger \& Goldberg this issue 36) But if I am deciding according to my own opinion then I am not blindly deferring to the minipublic in my sense of the term. My decision, far from (politically) blind, is the one aligned with my interests, values and policy objectives. Moreover, 'skipping further examination' of the minipublics' sources and arguments that favor what one already believes, in the absence of any challenge or counterevidence, is also not a form of informational blindness. It is a sound epistemic practice.

In the second case that the authors focus on we are ambivalent about the issue at hand and in the third case the minipublic's recommendation directly challenges our pre-existing opinion. In both cases, they argue, further engagement with additional sources and arguments produced by the minipublic is necessary. I agree. This is also their recommendation in a fourth type of case, namely, when the minipublic's recommendation bears a very low level of consensus (52\%), which signals that the issue is contested and thus that citizens need to pay closer attention to it.

I find the authors' recommendations for all four types of cases completely plausible, but I fail to see how any of them constitute cases of 'trust-based' uses of minipublic recommendations of the kind proposed by MacKenzie \& Warren (2012) that, in my view, do involve blind deference. In such cases non-participating citizens 'trust' minipublics in that, instead of making up their own mind on the issue in question, they defer to the minipublics' recommendation-for example, when they are called on to vote in a referendum. Because they are trusting the minipublic, they do not need to examine the information and reasons justifying the recommendation. Clearly, cases 2, 3, and 4 do not involve any trust-based uses of minipublics in that sense, since citizens are supposed to examine additional, independent sources and arguments in order to make up their own minds on the issue. Case 1 does not appear to involve a trustbased use of minipublics either, since citizens are voting according to their own pre-existing opinion. In order to determine whether the authors' approach supports trustbased uses of minipublics (and is therefore incompatible with my approach) we would need to know their position regarding the paradigm case of such uses-a type of case that they do not discuss.

MacKenzie \& Warren (2012) recommend such uses for citizens who decide to remain 'passive' about some political issues. Since citizens do not have the time or interest to make up their minds about every political issue that they might be called upon to vote for, minipublics' recommendations can be useful for those citizens who do not have pre-existing opinions about the issues in question. They can trust minipublics' recommendations and vote accordingly without inspecting their sources of information or any arguments for or against a policy. The assumption here seems to be that such uses do not involve blind but 'warranted' deference because all nonparticipating citizens can trust that the majority of the minipublic shares their beliefs and values. In the book I argue that, since this assumption can't be true whenever minipublics' recommendations fall short of unanimous consensus, such trust-based uses of minipublics would actually require blind (or unwarranted) deference. Citizens simply have no more reason to assume that the majority of a minipublic shares their beliefs and values than they do to assume that the minority does.

I am not sure whether Bächtiger and Goldberg would accept this type of case. They recognize that there are some political issues about which they have very strong opinions' (Bächtiger \& Goldberg this issue: 39) so they concede that 'minipublic recommendations that contradict these opinions will hardly induce us to revise them.' (ibid.) So let's imagine that a recommendation they strongly oppose received a boost of blind support from 'passive' citizens who had no views on the issue and who endorsed it for the sole reason that it was recommended by the majority of minipublic participants. As a consequence, the recommendation received $80 \%$ instead of $65 \%$ of the votes, giving the misleading impression of an extraordinarily high level of support among the citizenry. This illicitly 'boosted' signal could have quite devastating effects for those fighting against that policy recommendation. Would such a trust-based use of minipublics strike them as fostering democratic self-government? I hope not. But if they do support such uses, their approach would actually endorse blind, not 'semi-blind' deference.

\section{Representation as Embodiment: Are All my Fellow Citizens 'like me'?}

The question at stake in trust-based uses of minipublics is the focus of James Pow's, Lisa van Dijk's and Sofie Marien's very interesting empirical study. Do citizens think that minipublics' participants are 'like them'? If so, is it for that reason legitimate to either expect or require citizens to blindly defer to minipublics' decisions? At the risk of stating the obvious, let me begin by pointing out that, 
while the first question is empirical, the second question is normative. The legitimacy perceptions of citizens cannot settle the second question any more than the legitimacy perceptions of political scientists or political philosophers can. Normative questions can only be settled by the quality of the arguments put forward. With respect to the first, empirical question, I find the hypotheses at the center of their study very interesting. However, they raise questions that I am not sure can really be answered on the basis of the sort of empirical data that was gathered in this study. They might need to carry out experiments in which more fine-grained questions are asked of survey respondents so that it is possible to draw some more specific conclusions on the issue of trust and blind deference. Let me mention some of the issues.

One difficulty that I see with the study is that different types of similarity are used in various questions that are asked to respondents, but these differences do not seem to be properly reflected in the conclusions. Everything is similar to everything else in some respect or another. 'Similar' is a specification-dependent term. So, it is always crucial to know the specific sense of 'similarity' that is at stake both when questions are asked and also when inferences are drawn from responses. For example, when evaluating the important question of respondents' 'decision acceptance' of minipublics' recommendations we are told 'respondents were significantly more likely to accept the overall outcome of the citizens' assembly when they perceived the participants to be like them even when controlling for outcome favourability' (Pow, van Dijk \& Marien this issue: 50). However, we are not told in which respects participants needed to be 'like them.'

The overall suggestion in the paper is that the key similarity trait is that participants are 'ordinary' citizens. It is indeed very plausible that citizens trust their fellow citizens in some generic and vague sense. But this generic trust is not sufficiently specific to draw conclusions about citizens' willingness to blindly defer to minipublics. In fact, the data of the study seem to confirm this. When the authors ask survey respondents whether minipublic participants are 'like them,' we are told that the relevant contrast is 'politicians.' Thus, it is the feature of participants being 'ordinary' citizens that matters. However, once the authors introduce a further specification, namely, the political issue at stake, they expect respondents to distinguish between participants 'who are like them on the particular trait that is relevant to the minipublic's task' (Ibid 46) and those who are not. In other words, as soon as more specific, politically relevant questions are asked, respondents readily judge some participants within minipublics as not being 'like them' even though they are ordinary citizens. Moreover, the authors expect this distinction to impact the legitimacy perceptions of respondents. Indeed, the study's findings support this hypothesis (H2). For respondents, the inclusion of participants who are 'like them' in the generic sense of being ordinary citizens is insufficient for the legitimacy of minipublics. Respondents insist upon the inclusion of enough citizens who are like them on the particular trait that is relevant to what is politically at stake (Ibid 51).
This difference is directly relevant to the issue of blind deference in my sense of the term. Indeed, it seems that citizens are not willing to blindly defer to ordinary citizens as such. To the contrary, they are willing to defer to those 'citizen-representatives' who share the trait most relevant to what is politically at stake. If this is so, then generic 'like me' judgments are not a sufficient indicator of legitimacy perceptions. Substantive political representation matters more. This observation also seems to challenge the authors' conjecture that the relevant bond between citizens and minipublics participants 'is affective, not substantive' (Ibid 45) Yet, things get even muddier. For, it turns out that respondents also reject the idea of including in minipublics only members who are 'like them': 'nonparticipants still find it important that ordinary citizens who are not directly like them in terms of specific traits are also present in the minipublic. This is even true if these other ordinary citizens belong to the "'opposing camp" on the issue at stake' (Ibid 50). In sum, it seems that respondents genuinely albeit tacitly appreciate that, to the extent that minipublics mirror the citizenry, it simply cannot be the case that all participants are 'like them.' Some will share their beliefs and values and others won't. This, in turn, is relevant for whom they see as legitimately representing them among all participants; not just any 'ordinary' citizen will do.

Taking all of this into account, let's examine hypothesis H1a: 'the more non-participants perceive minipublic participants to be "like them," the more legitimate they perceive minipublics to be.' (Ibid 45) If we take this hypothesis as a comparative statement then we face the problem that we do not know the specific respects in which citizens need to be more similar to one another. ${ }^{6}$ If we interpret the relevant similarity in terms of specific traits, it is simply not true that the more participants are "like them' the more legitimate minipublics are seen to be. The opposite seems to be true, since including participants who are their exact opposite ('in the opposing camp') also seems important to respondents. Thus, as stated, the hypothesis seems disconfirmed. But if one interprets the relevant similarity as being 'ordinary' citizens then the hypothesis is also disconfirmed. For it is also not true that, so long as all participants are ordinary citizens, the minipublic would be seen as 'legitimate'. Again, according to the respondents, including citizens who are "like them on the relevant trait for the issue at stake' is also necessary for legitimacy. This strongly suggests that one needs more fine-grained hypotheses in order to draw specific conclusions on the issues of trust, blind deference, etc. Nevertheless, I would like to give some tentative impressions about the data.

Like many minipublic enthusiasts, the authors seem to embrace the populist notion of representation as 'embodiment.' According to that notion, minipublic participants 'speak like the people, rather than for them' (Ibid 45). I find this notion of representation highly problematic. $^{7}$ The relationship of embodiment can only work under the assumption of a homogenous 'people' whose members share the same interests, values, and policy objectives. They can trust each other because 
everyone is politically like everyone else. Note that the assumption of homogeneity is essential. For, if 'the people' were politically divided (if they had conflicting beliefs and values) then it would be impossible for everyone to speak like everyone else. By being like some citizens, one would necessarily be unlike others. As we are currently witnessing, the main problem with using this populist notion of representation is that, in the face of legitimate political disagreements, the tacit default assumption of homogeneity can only be maintained by identifying the majority as the 'real people' and excluding dissenting minorities (e.g. as 'enemies of the people' who do not speak like them). Looking at the study's data from this perspective, I find the respondents' nuanced judgments on similarity, political representation, inclusion, and legitimacy reassuring. They do not seem to share the populist notion of representation as embodiment nor do they seem to share the populist hostility towards politicians that would certainly have provided strong confirmation of hypothesis H1b.

\section{Empowered Minipublics as Second-Best Strategy}

But what are the consequences of rejecting the assumption of homogeneity and recognizing that citizens living under free institutions have different interests, values, and policy objectives which give rise to legitimate political disagreements? From a democratic point of view, the most important consequence is that citizens can only legitimately further their interests, values, and policy objectives if they resolve their disagreements with their fellow citizens who have equal rights to be co-legislators. They need to change each other's hearts and minds. Such mutual learning processes require actual political struggle. They cannot be wished away, bypassed, or delegated to the few in the hope that they will do the thinking and deciding for us and that we can then simply follow them without learning. This won't be democratic, and it won't work.

Keeping this insight in mind, my claim about the desirability of empowering minipublics must be understood as a conditional claim. If one agrees that blind deference is inimical to democracy (my main claim), then the issue of whether one should endorse giving decisional power to minipublics should depend on whether this will require citizens to blindly defer to their decisions. I agree with Mansbridge that, at this historical juncture, we do not know much about the consequences, modalities and possibilities of using deliberative minipublics. But, precisely for that reason, when evaluating their democratic potential, it is very important to carefully examine whether their institutionalization would enable citizens to identify with the laws and policies to which they are subject and endorse them as their own or whether it would have the opposite effect over time. From a democratic perspective it makes all the difference in the world whether minipublics are thought of as ways to empower the citizenry or as ways to bypass the citizenry in the hope that minipublics' participants will do the thinking and deciding for us.

In his contribution, Jim Fishkin challenges this argument. He does not seem to believe that minipublics could serve the participatory goal of empowering the citizenry. If I understand him correctly, he thinks that such a participatory goal could be served by institutionalizing something along the lines of Deliberation Day, but not minipublics. Apparently, we basically have two options with respect to the latter. Minipublics can either be empowered to directly make political decisions bypassing the citizenry or they can serve as a source of information for the citizenry-in which case they are reduced to 'mere talk' with no political impact. This view leads Fishkin to paint the following picture. A participatory deliberative democracy is the first-best strategy towards achieving a deliberative society. But this strategy has no need of or use for minipublics. Minipublics are needed whenever mass participation in quality deliberation is not a realistic option. Under non-ideal conditions, minipublics are a secondbest strategy. This is so because minipublics can make a high-quality impact on decision-making only if they are directly connected to the political system while bypassing the actual low-quality processes of public opinion and will formation in which the citizenry participates.

My problem with this line of argument, contrary to what Fishkin suggests, is not that I am not willing to settle for less than a 'first-best' strategy. I am perfectly happy to embrace any second-best strategy that would get us closer to the same goals as the first-best strategy. But we can't use a non-participatory strategy to reach participatory goals. We can't get closer to democratic self-government by empowering the few to make decisions and then expect the many to blindly follow them. This strategy would get us farther away from the goal.

To my own surprise, I have the impression that I am more optimistic than Fishkin about the democratic potential of minipublics. I do not see why institutionalizing minipublics could not be part and parcel of a first-best strategy for reaching participatory goals. First of all, the fact that minipublics are not themselves institutions of mass participation is not an argument against their potential to serve participatory goals like improving the quality of deliberation by the citizenry. Newspapers contribute to the quality of public deliberation without having to be structured like Wikipedia. As I argue in the book, even the institutions of judicial review, institutions which are paradigmatically not amenable to mass participation, can decisively serve participatory goals by enhancing the communicative power of minorities and in so doing improving the overall quality of deliberation in the public sphere. From a participatory perspective it is not simply the participation of those who actually file lawsuits that matters but rather their effects on the public debate about contested issues (more on this later). Besides this, I also do not see why minipublics can have an impact on the political system only if they are empowered to make decisions that bypass the citizenry.

It is true that minipublics cannot generate power on their own. But they can certainly enhance or challenge existing political powers. If this is true, then why not enhance the political power of the citizenry while also improving the quality of the processes of opinion and will formation in which citizens participate? In all the examples that I discuss in the book, I rely on already 
existing and organized political actors whose power could be enhanced by minipublics if their institutionalization were generalized in democratic societies. For example, in the case of contestatory uses of minipublics, I rely on the existence of social movements and political organizations who have already embarked upon political struggles to change the hearts and minds of their fellow citizens with respect to some contested issue. They make strategic use of a variety of existing institutions to further their political goals (from writing op-eds in media outlets to filing lawsuits, organizing strikes, lobbying politicians, and so on). If minipublics were institutionalized, then these institutions could also be added to their toolkit. It is the political activism of already mobilized civil society groups that would prevent minipublics' recommendations from falling on deaf ears or being reduced to 'mere talk.' Similarly, vigilant uses of minipublics rely on entry points to the political system that already exist such as ballot initiatives, referenda, etc. Minipublics' recommendations could decisively enhance the deliberative quality of citizens' own political decisions especially if they offered citizens key information for understanding what is at stake and evaluating the most important reasons for and against a certain policy. The same insight applies to the anticipatory uses of minipublics that I discuss in the book. In fact, these uses speak against the view that minipublics can only be remedial or second-best options. Fishkin claims that in a democracy wherein nearly everyone deliberates there would be no need for minipublics such as Deliberative Polls. I do not see why that would be so. Regardless of how good the quality of deliberation among the citizenry in a democratic society might become, the sheer amount and complexity of political decisions ensures that it will always be necessary to divide political labor. As long as this is the case citizens will need trustworthy informational shortcuts in order to make up their own minds on the merits of a variety of political issues, especially issues that are new or uncertain. Minipublics could certainly fulfill that function by making the most relevant information and the most important reasons for and against their proposals available to the citizenry. They could provide democratic shortcuts to empower citizens in their fight against the many existing anti-democratic shortcuts that enable powerful actors to directly influence the political system while making it less and less responsive to citizens' interests, values, and policy objectives.

Ronald van Crombrugge's defense of 'citizen-initiated citizens' assemblies' offers an excellent example of what a participatory use of minipublics could look like if that use were crafted to empower the citizenry. As he explains, citizen-initiated minipublics would enhance the agendasetting capacity for the citizenry while also combining it with the deliberative qualities of minipublics (i.e. safeguarding the quality of information and preventing deliberative exclusions). Since the recommendations of minipublics would be coupled with formal law-making procedures this would ensure that they wouldn't be 'mere talk.' However, since the citizenry would determine the proposals that minipublics would evaluate, this use of minipublics would empower citizens to make the political system more responsive to their interests, values, and policy objectives over time. Granted, in order to serve this function minipublics would have to have some decisional power. After all, those proposals that do not survive the scrutiny of a minipublic's majority would not be recommended to parliament for consideration. This gives me the opportunity to address a question that Fishkin poses that highlights a need for some clarification.

If an institution serves a function it will necessarily exercise some decisional power. I do not oppose any and all forms of decisional power for minipublics. What I oppose is a form of decisional power that bypasses the citizenry while connecting up directly to the political system. However, if the institution in question is designed to serve participatory goals then the fact that it exercises some decisional power is not a problem per se. This is particularly clear in the case of the institutions of judicial review. The fact that Supreme Courts have strong decisional power does not rule out that they serve important participatory goals. As I argue in the book, these participatory goals justify their democratic legitimacy. In my view, before determining whether or not an institution serves democratic goals, one has to pay attention to the functions that it serves within the entire system.

Citizen-initiated minipublics are but one example and I agree with Van Crombrugge that one should not underestimate the many difficulties and hurdles involved in institutionalizing minipublics. However, the example of citizen-initiated minipublics deftly highlights the fundamental difference between designing minipublics with an eye towards fulfilling participatory aims versus designing them with an eye towards bypassing the citizenry. My book aims to inspire all those who are involved with the institutionalization of minipublics to direct their efforts towards participatory proposals. Granted, this process is likely to be hard. As Van Crombrugge vividly illustrates, the fact that the Flemish Citizen's Assembly Bill proposal was voted down by the Flemish Parliament, even under quite ideal conditions, clearly indicates that such a project will be an uphill struggle. Besides 'the chicken and egg problem' that he identifies, the biggest hurdle is indeed the predictable unwillingness of politicians to share power with others. However, these difficulties are likely to be the same whether the aim is empowering the citizenry or the random few. If pitched political struggle is equally necessary along each path, then we may as well try the former and get more democracy as a result.

\section{Ordinary politics vs Constitutional Challenges: Can Citizens take off their Robes?}

In the discussion of blind deference above, I passed over one important issue raised by Goodin. Doesn't my institutional approach also require blind deference? After all I recognize that, especially within pluralist societies, not every citizen can endorse every single decision they are subject to. Therefore, the approach I defend seems to suppose that citizens will be able to endorse those institutions that enable them to express dissent and contest decisions while also blindly accepting substantive decisions that they cannot endorse as their own. If this characterization is correct, then how is this any different from simply endorsing majoritarian institutions despite 
the fact that one cannot endorse all their substantive decisions? I think that there is a subtle yet important difference here.

Deep pluralist approaches defend the legitimacy of majoritarian institutions and reject non-majoritarian institutions (such as judicial review) as democratically illegitimate. On this approach citizens are expected to blindly (and voluntarily) defer to majoritarian decisions that they disagree with because this is the legitimate thing to do. To be more precise, this approach expects citizens to (voluntarily) accept majoritarian decisions-whatever they might be (i.e. blindly)-as perfectly legitimate for the sole reason that they are endorsed by the majority. By contrast, the institutional approach I defend never expects citizens to (blindly and voluntarily) accept the legitimacy of all majoritarian decisions simply because the majority endorses them.

According to my normative reconstruction, the institutions of constitutional democracies operate under the assumption that political decisions that touch upon citizens' fundamental rights and freedoms cannot be legitimately settled by majority rule. To put this the other way around: these decisions are not legitimate simply because they are endorsed by the majority. They can be contested and must be settled on substantive grounds. On my approach this is the specific sense in which institutions never require or expect citizens to blindly defer to majoritarian verdicts on these issues (i.e. to accept them as legitimate simply because the majority endorses them). Goodin suggests that this is little consolation for those engaging in legal contestation if the courts end up ruling against them. I actually disagree. As I argue in the book, the review process cannot guarantee that every citizen's views will prevail. Indeed, given that citizens disagree, no process could deliver that result. However, the losing side gets something very valuable from the fact that this process-in contrast to other possible processes (e.g. decisions by secret ballot)-is rooted in a public debate about substantive reasons: they receive specific and reasoned evidence for the legal decisions in question that they can then use to more effectively challenge them in the future. This gives citizens a unilateral power to reopen the public debate and to try to win the hearts and minds of their fellow citizens on the basis of reasons, not numbers.

This insight raises another important issue that is at the center of Simone Chambers' contribution. Is my democratic re-reading of judicial review supposed also to provide a constitutionally focused alternative conception of deliberative democracy? It very much depends on what one mean by this. If this is supposed to mean that judicial review furnishes the paradigmatic institutional opportunity for the exercise of a participatory conception of deliberative democracy then my answer is a resounding 'No'. This is not how I understand the democratic significance of judicial review. But the fact that several commentators got this impression makes me fear that the structure of the book (culminating as it does with a discussion of judicial review) may, against my own intentions, be misleading and that I should have been clearer on this point so as to prevent misunderstandings. Let me briefly explain my views here.
What I call a participatory conception of deliberative democracy is an alternative to an epistemic conception of deliberative democracy. The latter sees the importance of political deliberation in the epistemic benefits of identifying 'better' policies 'faster,' which will then lead to better political outcomes. On the basis of this understanding of deliberation the functions and significance of the various political institutions, the public sphere, and the deliberative system as a whole are interpreted from an exclusively epistemic perspective. ${ }^{8}$ By contrast, a participatory conception of deliberative democracy understands the importance of political deliberation in terms of enabling citizens to participate in a project of self-government. On the basis of this understanding of deliberation I offer an alternative interpretation of the significance of the very same political institutions and democratic sites that are the focus of other democratic conceptions. When one adopts a citizen-centered perspective of analysis these familiar institutions acquire a different significance because the questions we are trying to answer are different. Can citizens endorse the political institutions that they are subject to upon reflection? Once they understand their function and significance, can citizens take ownership over these institutions? Can they see themselves as equal participants in a political project of self-government?

The point and rationale behind articulating a participatory perspective is not to identify a paradigmatic institutional opportunity of participation that would be different from or better than those identified by epistemic conceptions of deliberative democracy (e.g. epistocracy or lottocracy). Not at all. The aim is to offer a different understanding of the existing institutional opportunities of participation in democratic societies as well as of those that may be created in the future. In that spirit, the book offers an alternative interpretation of democratic innovations such as minipublics. It also offers a democratic interpretation of the institutions of judicial review. However, this interpretation does not try to elevate legal contestation to the quintessential exercise of self-government. Nor, for that matter, does it try to elevate participatory uses of minipublics to such a special status. This is the case not so much because I think that some other exercise of political rights (e.g. voting) is more quintessential. Rather, it is because none of them can have genuine democratic significance in the absence of all the others. In the absence of a mobilized civil society and a receptive public sphere legal contestation would hardly have any democratic effects at all. Conversely, voting in the absence of effective opportunities for legal contestation would hardly count as an exercise in selfgovernment for persistent minorities. These are just two examples. However, the idea of mutual reinforcement holds for all opportunities, venues, and sites of citizen participation. My overall aim (and hope) is that a participatory interpretation of deliberative democracy can offer some guidance to citizens' political struggles towards institutional reform and democratization. At the very least, this conception can help citizens identify those proposals that would eliminate existing antidemocratic shortcuts that prevent the political system to be properly 
responsive to their interests and values and those proposals that would add antidemocratic shortcuts and could therefore make things worse, even with the best democratic intentions.

This brief explanation helps answer another important concern that Chambers raises, namely, whether a citizen-centered participatory perspective is unduly individualistic. Does adopting this perspective involve 'imagining each individual potentially engaging in mutual justification?' Is this perspective compatible with the Habermasian feedback loop model of public deliberation that I endorse in the book or does this model require adopting a system view, instead of a practice-view? As for the first question, adopting a participatory conception requires justifying the constitutive norms, function, and significance of democratic institutions from the internal perspective of citizens who are expected or required to make use of them. Only from within a practice view is it possible to show that citizens can endorse these institutions upon reflection. In that sense, yes, a plausible conception of democracy must be able to show that political institutions enable citizens to respect the priority of public reasons when defending the policies that they favor such that all citizens can see themselves as equal participants in a project of self-government. However, as I repeatedly insist throughout the book, this does not mean that deliberation should be thought of in terms of a face-to-face model-as if it were the sum of all synchronic conversations between individuals on political issues that take place at a particular time. This touches upon the second question.

In line with Habermas's feedback loop model, I understand deliberation as a diachronic process that takes places in many different ways at multiple sites and with constant variation among participants over time. One crucial aspect of this model is that it views communication as a circular process in which some topics can become the object of debate among interlocutors only against the shared background of tacit presuppositions (i.e. beliefs, values, norms, attitudes, etc.) upon which all participants draw. That 'lifeworld' reservoir of shared presuppositions, in turn, is being constantly transformed as a result of the outcomes of all the different communication processes. Insofar as members of a political community share this lifeworld they are passively 'participating' in the ongoing transformation of beliefs, values, and mentalities that is produced by the contributions of a variety of actors and that generates shared convictions. These communication processes range from institutionalized political discourses to more diffused discourses in the media, in everyday communication in civil society, in subaltern publics, and so on. The deliberative system perspective can be fruitful for understanding the interconnections between all the different sites and varieties of political deliberation that are simultaneously taking place in society. However, I think that it would be a mistake to equate adopting a holistic perspective towards the deliberative system with adopting a merely functionalist analysis that is undertaken from the third-personal perspective of a 'detached observer.' Like all other political institutions, the deliberative system must also be evaluated from the normative, internal perspective of participants in order to see whether it contributes to the democratic legitimacy of political decisions or, if it does not, how it should be properly transformed or improved.

Another important question that Chambers raises is whether my approach limits 'deliberation' to debates about constitutional questions and, as a consequence, relegates ordinary politics to processes of compromise, bargaining or majoritarian decisions that are outside deliberation proper. If this were the case, then deliberative democracy would have little to say about the type of ordinary politics that constitutes the bulk of citizens' political activity. If I understand her argument correctly, she suspects that this may be the case because (1) I endorse a public reason view of deliberation and, since (2) public reason constraints apply only to debates about rights, then it must follow that (3) 'deliberation is appropriate to answer questions about rights [but] not everyday wrangling over policy. (Chambers this issue: 79) I don't endorse this view. I agree with the first assumption but disagree with the second. This is why the conclusion does not follow.

In my view, political deliberation is typically and for the most part about justifying collective goals, setting proper priorities among them, and determining the most efficient means to reach them under conditions of scarcity. Political deliberation can also concern how best to protect and promote desirable social practices and institutions, as well as a variety of other goals. I also believe that political deliberation should be governed by public reason constraints. However, I reject the exclusion model of public reason and instead propose a prioritization model. On this basis, my argument in the book goes against standard Rawlsian views, in that public deliberation about laws and policies, in my view, cannot and need not be neutral towards conceptions of the good. To the contrary, it seems quite clear that a crucial element of advocating for the adoption of a specific policy is that one offers arguments and reasons that purport to show why the practices the policy regulates are good, beneficial, worth protecting, or whatever the case may be. Citizens do not necessarily have 'to put on their robes,' so to speak, in order to deliberate about these important political questions. However, this does not mean that when they 'take off their robes' they are not deliberating or that their deliberation should not be governed by the constraints of public reason, as Chambers seems to assume.

So long as there is no particular reason to assume that a policy under discussion is incompatible with the protection of some fundamental rights and freedoms, public deliberation will typically be about whether or not the policy's enactment would be beneficial, desirable, advantageous or whatever the case might be. Citizens participating in these sorts of debates will be offering reasons for and against a policy that draw upon their own interests, values and goals as articulated by whatever (religious or secular) comprehensive doctrines they happen to hold. However, as soon as some citizens don their robes and object that the policy in question violates a fundamental right or freedom, then their fellow citizens will have to follow suit and prioritize the settlement of that question before they can resume their deliberation on any of the other issues related to that policy. Does this 
mean that before the citizens 'put on their robes' their deliberations are not governed by public reason constraints or that they do not need to respect the priority of public reasons? Not at all. A situation like the one described, in which no one had any particular reason to suspect that the policy in question may violate some fundamental rights or freedoms, is a situation in which everyone involved believed that enacting that policy would respect the priority of public reasons. This is why their deliberation was focused on everything else that matters for deciding whether or not to enact the policy in question. The priority of public reasons may be inconspicuous when citizens have not yet donned their robes. But that does not mean that it is not respected. To the contrary, any suspicion that that priority has been violated would require citizens to put on their robes, no matter how 'ordinary' the policy under deliberation may be.

\section{Is My Democratic Conception State-Centric? The All Subjected vs All Affected Principle}

Mark Warren and Tetsuki Tamura are correct that my book adopts a state-centric view, at least in the sense that it does not address subnational and transnational institutions or issues of global democracy. Ironically, the main reason that I had given up on writing a book about democracy years ago is that normative democratic theory is remarkably state-centric and thus, in the wake of globalization, misses a lot of where the action is. However, the current crisis of democracy has shaken my (complacent) assumption that we can take democracy for granted at the state level (at least in the richest countries of the world) and worry only about how to extend democracy everywhere else. The fear of democratic backsliding and the erosion of democratic institutions at the state level is what motivated me to write this book, even though doing so meant that I had to ignore my own criticisms (levied over the past decade) of state-centric approaches in my work on global governance institutions and international human rights. Having said this, I hasten to add that my apparently 'state-centric' focus is a contingent not an essential feature of the participatory conception of deliberative democracy that I defend. I completely agree with Tamura's claim that this conception is compatible with 'a pluralized understanding of both self-government and sites of democracy' and (Tamura this issue: 93) and should be further developed in that pluralistic direction.

However, I disagree with Warren's suggestion that overcoming a state-centric view of democracy requires replacing the 'all-subjected' principle with the 'allaffected' principle. In my view, these principles fulfill different functions and are therefore best understood as complementary rather than in competition. This is a complex topic and I do not have the space to discuss it in depth here, but let me just briefly mention my take on the complementarity of these two principles. In my view, justice requires us to rightfully regulate our interactions among all those whom we cannot avoid affecting (the all-affected principle) and democracy requires that all those subject to these regulations can see themselves as their authors (the all subjected principle). ${ }^{9}$ Among other things, the first principle requires us to rightfully regulate externalities and the second requires us to give a say to all those subject to the regulations in question.

In my opinion, we can avoid counterintuitive interpretations of these principles only if we keep their distinctive functions separate. For example, keeping the principles separate can help to prevent interpretations that would take the 'all affected principle' as a principle of demarcation, i.e. as a principle of exclusion rather than inclusion. Under such an interpretation of the principle, only those directly affected by the relevant interactions ought to have a say on their proper regulation. The counterintuitive consequences that this would yield are particularly salient in the context of regulations that infringe upon fundamental rights and freedoms. Regulations that violate human rights ought to be everyone's concern, whether or not everyone is likely to be directly affected by them. Everyone ought to have a say on the proper legal protection of everyone's human rights. But this is not because or to the extent that we may be directly affected by the regulations in question. To the contrary, if we all have a duty of justice to reach a rightful condition with all those with whom we cannot avoid interacting (i.e. those we affect with our actions) then we cannot 'outsource' that duty just to the parties who are most directly affected by some of these interactions, regardless of what is at stake and regardless of existing power inequalities among them. To do so would likely leave the most vulnerable unprotected. Foreigners who live outside a country's jurisdiction may not be directly affected by its regulations permitting the imprisonment of homosexuals or stoning adulterous women to death, but they ought to have a say in undermining such regulations. On the other hand, keeping the complementarity between both principles also helps avoid an unduly narrow interpretation of the 'all subjected' principle. Endorsing this principle within democratic theory (i.e. as a principle of inclusion in decision-making), is not per se problematic in the sense that worries Warren, so long as our democratic theory is complemented with a theory of justice that justifies the duty to rightfully regulate all our interactions with those we cannot avoid affecting. This is the task of a cosmopolitan project of global justice that, in my opinion, requires us to defend a global participatory democracy. But, as I mention at the end of the book, that is a task for another book.

\section{Notes}

${ }^{1}$ For an overview of the debate see Habermas 2003: 237-276; and Lafont, 1999: 315-360; Lafont 2003, 2004, 2012.

${ }^{2}$ I am being cautious here for the following reason. On the one hand, Warren explains 'warranted trust' as follows: 'When individuals trust, they suspend judgment. But in a warranted trust relationship, judgments are suspended, not because individuals are "blind," but because [they] have made a prior judgment that their interests or values align with those of the trusted agent.' (Warren this issue: 86) So understood, the distinction between warranted and 
unwarranted trust corresponds quite precisely to the distinction between politically blind and non-blind deference, and this captures the specific sense of blind deference focused on in my book. On the other hand, in his contribution Warren seems to wrongly assume that I use the term in the broader sense of 'reflectively blind' deference, when he claims: "By "blind," Lafont means that deference lacks any reasons or empowerments with respect to those making decisions and enforcing laws and policies.' (Ibid 83). This makes me wonder whether Warren himself ever uses the term 'warranted trust' in the broader sense of having any reason at all to trust, even if the reason in question has nothing to do with the expectation of alignment of interests and values in particular. If he does, then his use of the warranted/unwarranted trust distinction would not coincide with my use of the blind/non-blind deference distinction and, consequently, our substantive views about the kind of deference/trust that is democratically acceptable could also differ.

${ }^{3}$ I agree with Mark Warren that deference is generally understood to be voluntary. When I use formulations in the book such as that citizens may be 'forced to blindly defer' to the decisions of others, I am adopting the perspective of citizens who are evaluating ex ante whether specific institutions are democratically legitimate and deserve their endorsement. It is from this perspective that I claim that institutions with antidemocratic shortcuts would leave citizens no alternative but to blindly defer to the decisions of others and, for that reason, democratic citizens should not endorse them upon reflection.

${ }^{4}$ I am accepting the features of the hypothetical case as it is described. But, to avoid giving the wrong impression, let me mention that I find the purely 'quantitative' nature of the argument highly problematic. Citizens are likely to care less about how frequently they will get their way and much more about what will be at stake when they lose. If protecting their fundamental rights and freedoms takes priority then they won't accept purely majoritarian institutions. I am assuming, for the sake of the argument, that our hypothetical citizen does not care about this distinction.

${ }^{5}$ The required revisions and adjustments will be more or less wide-ranging depending on how deeply embedded or peripherical the beliefs in question are within our overall inferential web of beliefs.

${ }^{6}$ We also face the problem that we do not know the specific functions, powers or authorities about which legitimacy questions are asked. As stated, the hypothesis fails to specify the functions for which minipublics are supposed to be 'legitimate'-for example, for advisory purposes (as it was asked in the survey) or in order to make binding decisions? Respondents' legitimacy judgments are likely to vary depending on the particular functions that are ascribed to minipublics.

${ }^{7}$ I offer a detailed analysis and critique in Lafont, forthcoming.

${ }^{8}$ By contrast, the participatory conception of deliberative democracy that I defend in the book endorses a pluralist conception of legitimacy, as Mansbridge rightly shows. I do not discuss this issue explicitly in the book, but I offer a brief analysis of the advantages of a pluralist conception of legitimacy over the monistic conceptions defended by epistocrats and deep pluralists in my review of Nadia Urbinati's book Democracy Disfigured (Lafont 2015).

${ }^{9}$ Here I am (loosely) following Kant's rendering of the obligation to enter into a 'rightful condition (see Kant 1996: 305-314).

\section{Competing Interests}

I declare that I have no significant competing financial, professional, or personal interests that might have influenced the performance or presentation of the work described in this manuscript.

\section{References}

Gadamer, H. G. (1994). Truth and method. New York: Continuum.

Habermas, J. (2003). Truth and justification, translated by B. Fultner. Cambridge, MA: MIT Press.

Kant, I. (1996). The metaphysics of morals, edited by $\mathrm{M}$. Gregor. Cambridge: Cambridge University Press. DOI: https://doi.org/10.1017/CBO9780511809644

Lafont, C. (1999). The linguistic turn in hermeneutic philosophy. Cambridge, MA: MIT Press.

Lafont, C. (2003). Procedural justice? Implications of the Rawls-Habermas debate for discourse ethics. Philosophy and Social Criticism, 29(2), 163-185. DOI: https://doi.org/10.1177/0191453703029002143

Lafont, C. (2004). Moral objectivity and reasonable agreement: Can realism be reconciled with Kantian constructivism? Ratio Juris, 17(1), 27-51. DOI: https:// doi.org/10.1111/j.0952-1917.2004.00253.x

Lafont, C. (2012). Agreement and consent in Kant and Habermas: Can Kantian constructivism be fruitful for democratic theory? Philosophical Forum, 43(3), 277-295. DOI: https://doi.org/10.1111/j.14679191.2012.00425.x

Lafont, C. (2015). Book review of Democracy disfigured: Opinion, truth and the people by Nadia Urbinati. Constellations, 22(2), 326-328. DOI: https://doi. org/10.1111/1467-8675.12165

Lafont, C. (forthcoming). Deliberative minipublics and the populist conception of representation as embodiment. In C. Landwehr, T. Saalfeld, \& A. Schäfer (Eds.), The state and future of representative democracy-A comparative perspective. Cambridge: Cambridge University Press. 
How to cite this article: Lafont, C. (2020). Against Anti-Democratic Shortcuts: A Few Replies to Critics. Journal of Deliberative Democracy, 16(2), pp. 96-109. DOl: https://doi.org/10.16997/jdd.367

\section{Submitted: 11 July 2020 Accepted: 11 July 2020 Published: 14 October 2020}

Copyright: ๑ 2020 The Author(s). This is an open-access article distributed under the terms of the Creative Commons Attribution 4.0 International License (CC-BY 4.0), which permits unrestricted use, distribution, and reproduction in any medium, provided the original author and source are credited. See http://creativecommons.org/licenses/by/4.0/.

W Journal of Deliberative Democracy is a peer-reviewed open access journal published by University of Westminster Press. 